\title{
Ultrasonographic endometrial thickness measurement is predictive for treatment response in simple endometrial hyperplasia without atypia
}

\author{
Ultrasonografik endometriyal kalınlı ölçümü atipisiz endometriyal hiperplazi \\ tedavi cevabinda öngörücüdür
}

\author{
Enis Özkaya ${ }^{1}$, Vakkas Korkmaz², Yeşim Özkaya², Alptekin Tosun, Tuncay Küçükozkan², Hüsne Bostan ${ }^{4}$ \\ 'Department of Obstetrics and Gynecology, School of Medicine, Giresun University, Giresun, Turkey \\ ${ }^{2}$ Department of Obstetrics \& Gynecology, Dr.Sami Ulus Maternity and Children's Health Teaching and Research \\ Hospital, Ankara, Turkey \\ ${ }^{3}$ Department of Radiology, School of Medicine, Giresun University, Giresun, Turkey \\ ${ }^{4}$ Department of Obstetrics and Gynecology, Giresun Maternity Hospital, Giresun Turkey
}

\section{Abstract}

Objective: We sought to determine the predictors of treatment response in simple endometrial hyperplasia without atypia.

Material and Methods: We prospectively treated 67 women with simple endometrial hyperplasia without atypia who were administered cyclic oral medroxyprogesterone acetate $10 \mathrm{mg} /$ day for 12 days of luteal phase for 3 months and underwent control endometrial sampling after treatment. All subjects were evaluated in terms of age, gravidity, parity, body mass index (BMI), menstrual cycle, endometrial thickness, uterine fibroids, ovarian cysts, serum CA 125 levels, systemic disorders and cigarette smoking. All parameters were used to predict treatment success.

Results: Persistent hyperplasia was observed in 11 subjects. Endometrial thickness was significantly correlated with treatment failure $(\mathrm{r}=0.293, \mathrm{p}=0.015)$. In ROC analysis, endometrial thickness was found to be predictive for persistent hyperplasia (area under curve: $0.724, \mathrm{P}=0.019$ ). Optimal cut off value was calculated to be $16.5 \mathrm{~mm}$ with $64 \%$ sensitivity, $72 \%$ specificity and $91 \%$ negative predictive value. The number of persistent hyperplasia in women with and without endometrial thickness greater than $16.5 \mathrm{~mm}$ was significantly different ( $7 / 23$ vs. $4 / 45, p=0.029)$. Odds ratio of endometrial thickness higher than $16.5 \mathrm{~mm}$ for treatment failure was $4.4(95 \% \mathrm{CI}, 1.2-17.4, \mathrm{p}=0.03)$. Conclusion: Results of this study suggest treatment modification according to the baseline endometrial thickness in patients with simple endometrial hyperplasia without atypia.

(J Turkish-German Gynecol Assoc 2013; 14: 19-22)

Key words: Endometrial hyperplasia, medroxyprogesterone acetate, endometrial thickness, ultrasonography, atypia

Received: 13 October, 2012

Accepted: 8 February, 2013
Özet

Amaç: Bu çalışma ile atipisiz endometriyal hiperplazide tedaviye cevabı öngören faktörlerin belirlenmesi amaçlandı.

Gereç ve Yöntemler: Atipisiz endometrial hiperplazisi olup luteal fazın 12 günü boyunca 3 ay süreyle medroksiprogesteron asetat 10 $\mathrm{mg} /$ gün alan ve tedavi sonunda kontrol endometriyal örnekleme yapılan 67 hastayı prospektif olarak topladık. Tüm bireylerde yaş, gravida, parite, beden kitle indeksi, menstrüel siklusu, endometriyal kalınlık, uterin fibroidler, overyan kistler, serum CA125 değerleri, sistemik hastalıklar ve sigara içimi değerlendirildi. Tüm parametreler kullanılarak tedavi başarısı öngörülmesi amaçlandı.

Bulgular: Persistan hiperplazi 11 hastada izlendi. Endometriyal kalınlık tedavi başarısızlığı ile anlamlı korele idi $(r=0.293, p=0.015)$. ROC analizinde, endometriyal kalınlık, persistan hiperplaziyi anlamlı öngörmekteydi (area under curve: 0.724, p=0.019). Optimal eşik değer \%64 sensitivite, \%72 spesifisite, \%91 negatif prediktif değer ile $16.5 \mathrm{~mm}$ olarak hesaplandı. Persistan hiperplazi sayısı endometriyal kalınlığı $16.5 \mathrm{~mm}$ nin üstünde ve altında olan grupta anlamlı farklı idi (7/23 vs. 4/45, p=0.029). Endometriyal kalınlığın 16.5 mm'nin üstünde olması tedavi başarısızlığı ile ilişkiliydi [Odds oranı $=4.4(\% 95 \mathrm{CI}, 1.2-$ 17.4, $\mathrm{p}=0.03)]$.

Sonuç: Bu çalışmanın sonucu basit atipisiz endometriyal hiperplazide bazal endometriyal kalınlık ölçümünün tedavi modifikasyonunda etkili olabileceğini göstermiştir.

(J Turkish-German Gynecol Assoc 2013; 14: 19-22)

Anahtar kelimeler: Endometriyal hiperplazi, medroksiprogesteron asetat, endometriyal kalınlık, ultrason, atipi

Geliş Tarihi: 13 Ekim 2012 Kabul Tarihi: 08 Şubat 2013 


\section{Introduction}

Endometrial hyperplasia is defined as a proliferation of endometrial glands that may progress to or coexist with endometrial cancer. Endometrial hyperplasia considered to result from unopposed chronic estrogen stimulation. The treatment of endometrial hyperplasia is managed according to the risk of endometrial carcinoma. The classification system that correlates most closely with the risk of malignancy was suggested by the World Health Organization system (WHO) (1). This classification system includes four categories:

- Simple without atypia

- Complex without atypia

- Simple with atypia

- Complex with atypia

A cyclic regimen of medroxyprogesterone acetate (MPA, ie. 10 $\mathrm{mg} /$ day for 12 to 14 days each month) is a widely accepted regimen for treatment (2).

A previous study reported that regression was noted in 52 of 65 patients (80\%) with hyperplasia without atypia treated with MPA (3).

If regression to normal endometrium does not occur after three to six months, it was suggested that the progestin dose be increased, or a combination of a systemic progestin and the levonorgestrel intrauterine device may be used.

Usually obese women are encouraged to lose weight, which has multiple health benefits in addition to reduction of estradiol and estrone production by adipocytes. In a previous study it was concluded that cigarette smoking specifically affects the control mechanisms of intraovarian processes which are responsible for normal luteal function (4). Body mass index (BMI) was reported to be predictive of sonographic endometrial stripe thickness, which in turn is predictive of endometrial hyperplasia in patients with polycystic ovary syndrome. For every $1 \mathrm{~mm}$ increase in endometrial stripe in ultrasonographic evaluation, the odds ratio of hyperplasia increased by 1.48 (95\% confidence interval, 1.04-2.10) (5).

The aim of this study is to assess the predictors of treatment response in women with simple endometrial hyperplasia without atypia.

\section{Material and Methods}

Sixty seven premenopausal women diagnosed with simple endometrial hyperplasia between 2010 and 2012 at Dr. Sami Ulus Maternity and Women's Health Teaching and Research Hospital were enrolled for the study. Local ethics committee approval with subjects' informed consent were obtained before the study. Women were administered cyclic oral MPA $10 \mathrm{mg} /$ day for 12 days of the luteal phase for 3 months and underwent control endometrial sampling after treatment. MPA was preferred in order to make the results easily compared with previous studies in which MPA was the drug of choice. All subjects were evaluated in terms of age, gravidity, parity, BMI, menstrual cycle, endometrial thickness, uterine fibroids, ovarian cysts, serum CA 125 levels, systemic disorders, cigarette smoking. All parameters were used to predict treatment success.
Inclusion criteria were a diagnosis of simple endometrial hyperplasia in premenopausal women with abnormal vaginal bleeding or thickened endometrium, followed by progestin therapy for three months and post treatment endometrial samplings and without previous medical or surgical intervention for any endometrial pathology. Endometrial polyps were ruled out by an office hysteroscopic procedure in women with thickened endometrium. Premenopausal women without any symptoms underwent imaging at least twice, and persistence of an early-proliferative-phase endometrium thicker than 12 mm was an indication for office hysteroscopy and endometrial sampling (6). The final outcome was categorized as resolution, persistence, or progression based on the findings either at hysterectomy or in the two final, consecutive endometrial samples. Post-treatment specimens were obtained within 3 weeks of discontinuing progestins. Control endometrial samplings were obtained just after menstruation.

Patients were excluded if they were postmenopausal, if they had a history of other genital tract cancer, pelvic radiation, or hormonal therapy for breast cancer; or if either pretreatment or first follow-up specimen was unavailable for review. A pathologic review of the pretreatment and first follow-up endometrial specimens was performed independently by two gynecologic pathologists. When the two pathologists differed as to diagnosis, a third gynecologic pathologist was consulted; the majority diagnosis was used. Pathologists were blinded to the final outcome. The pretreatment and first follow-up endometrial specimens were classified based on the WHO criteria for the diagnosis of endometrial hyperplasia and carcinoma (7). Subject data were collected until resolution, hysterectomy, or loss to follow-up. Resolution was defined as the absence of hyperplasia or carcinoma in a hysterectomy specimen or in a minimum of two sequential endometrial specimens. Persistence was defined as any continued simple hyperplasia during treatment. During transvaginal sonography (TVS), the thickest part of the anteroposterior bilayer endometrial thickness was measured in the sagittal plane. Body mass index was calculated by body weight divided by height squared. Serum levels of carbohydrate antigen-125 (CA-125) were determined with use of the commercially available Tumor Markers CA 125 AxSYM ${ }^{\circledR}$ System (Abbott Laboratories; Abbott Park, IL, USA). All subjects were questioned about cigarette addiction, menstrual cycle, gravidity and parity. A blood loss of greater than $80 \mathrm{~mL}$ or lasting longer than 7 days constitutes menorrhagia. Metrorrhagia was defined as light bleeding from the uterus at irregular intervals. Menometrorrhagia was diagnosed in subjects with heavy bleeding from the uterus at irregular intervals. The subjects' smoking habits were obtained from the questionnaire, including current smoking habits, history of giving up smoking, duration of smoking habit and average daily cigarette consumption. A current smoker was defined as a subject who had smoked more than 100 cigarettes and was still smoking (8). An ex-smoker was defined as having stopped smoking for more than half a year (8).

An ovarian cyst was defined as any collection of fluid, surrounded by a very thin wall, within an ovary larger than about two centimeters. Diagnosis of adenomyosis was considered 
according to the clinical and imaging findings after ruling out other possible uterine pathologies.

Women with refractory hyperplasia were administered $20 \mathrm{mg} /$ day of metroxyprogesterone acetate for 12 days of the luteal phase for 3 months and underwent endometrial sampling.

\section{Statistical analysis}

The statistical analyses were performed using the Statistic Package for Social Sciences (ver. 12.0; SPSS Inc., Chicago, USA). Categorical variables were compared by Chi square test. Correlation analysis was used to show associations. p value $<0.05$ was accepted as statistically significant. ROC analysis was used to calculate cut off value. Binary logistic regression analysis was used to calculate the odds ratio.

\section{Results}

Mean age, gravidity, parity, BMI, endometrial thickness was $44.2 \pm 7.2$ years, $3.2 \pm 1.8,2.8 \pm 1.3,27.8 \pm 5.1 \mathrm{~kg} / \mathrm{m}^{2}, 14.1 \pm 6 \mathrm{~mm}$ respectively (Table 1). Mean number, size of myoma, CA125 levels were as follows; $1.6 \pm 0.9$ (range 0-5), $20.1 \pm 12 \mathrm{~mm}$ (range 6-57), $17.4 \mathrm{U} / \mathrm{mL}$ (range 5-104). Persistent hyperplasia was observed in $11(16.4 \%)$ subjects. The symptoms at the time of admission were menorrhagia $(n=10)$, metrorrhagia $(n=19)$, menometrorhagia $(n=28)$, vaginal spotting $(n=2)$ and without any symptom $(n=8)$. There were 35 women without any fibroids, 25 women had at least one fibroid, 7 women had adenomyosis. Endometrial polyp was not observed in any case. Forty-seven women had an ovarian cyst. Seven women had hypertension, 2 women had diabetes mellitus and 2 women had both disorders. Out of 67 women, 8 were smokers. Endometrial thickness was significantly correlated with treatment failure $(r=0.293, p=0.015)$. In the ROC analysis, endometrial thickness was found to be predictive for persistent hyperplasia (area under curve: 0.724, $\mathrm{p}=0.019$, Figure 1). Optimal cut off value was calculated to be $16.5 \mathrm{~mm}$ with $64 \%$ sensitivity, $72 \%$ specificity and $91 \%$ negative predictive value. The number of persistent hyperplasia in women with and without endometrial thickness greater than $16.5 \mathrm{~mm}$ was significantly different ( $7 / 23$ vs. $4 / 45, p=0.029$, Table 2 ). Mean age, BMI and serum CA125 levels were similar between subjects with endometrial thickness of greater and lower than $16.5 \mathrm{~mm}$ ( $p>0.05)$. The number of smokers and subjects with fibroids and ovarian cysts were similar between groups ( $p>0.05)$. Other

Table 1. Some demographic and clinical parameters of groups with and without thickened endometrium

\begin{tabular}{|l|c|c|c|}
\hline & $\begin{array}{c}\text { Endometrial } \\
\text { thickness } \\
<\mathbf{1 6} \mathbf{~ m m ~} \mathbf{( N = 5 6 )}\end{array}$ & $\begin{array}{c}\text { Endometrial } \\
\text { thickness } \\
\mathbf{1 6} \mathbf{~ m m ~} \mathbf{( N = 1 1 )}\end{array}$ & \\
\hline Age (years) & $44.3 \pm 6.8$ & $44.1 \pm 9.9$ & $\mathrm{NS}$ \\
\hline Gravidity & $3.1 \pm 1.7$ & $3.7 \pm 2.2$ & $\mathrm{NS}$ \\
\hline Parity & $2.7 \pm 1.3$ & $3.2 \pm 1.6$ & $\mathrm{NS}$ \\
\hline BMI $\left(\mathrm{kg} / \mathrm{m}^{2}\right)$ & $27.9 \pm 5.1$ & $27.8 \pm 6.2$ & $\mathrm{NS}$ \\
\hline ET (mm) & $13.4 \pm 5.7$ & $18.1 \pm 6.1$ & 0.015 \\
\hline BMI: Body mass index, ET: Endometrial thickness \\
\hline
\end{tabular}

parameters did not show any significant association with treatment success. The odds ratio of endometrial thickness greater than $16.5 \mathrm{~mm}$ for treatment failure was 4.4 (95\% CI, 1.2-17.4, $\mathrm{p}=0.03$ ). All persistent hyperplasia cases responded to higher doses of progesterone therapy.

\section{Discussion}

In this study we tried to assess some parameters to predict treatment response in women with simple endometrial hyperplasia and we found that solely ultrasonographic endometrial thickness measurement was significantly predictive for treatment response. Cigarette addiction, menstrual cycle, gravidity, parity and pelvic pathologies (i.e. myomas, ovarian cysts) were not found to be predictive for treatment response.

Based on the systematic review of the contemporary literature, $66 \%$ of endometrial hyperplasia cases respond to hormonal therapy. Disease persistence was found in $14 \%$ of cases (9). In our study population, $16.4 \%$ cases were refractory to the treatment. A recently published study questioned the value of endometrial thickness measurement to predict histeroscopic findings and concluded that hysteroscopy should be offered when thickened endometrial is found (10). In addition to this ,although attempts to introduce noninvasive new diagnostic tools have beenmade, transvaginal ultrasound remained one of the most effective methods to screen endometrial pathologies (11).

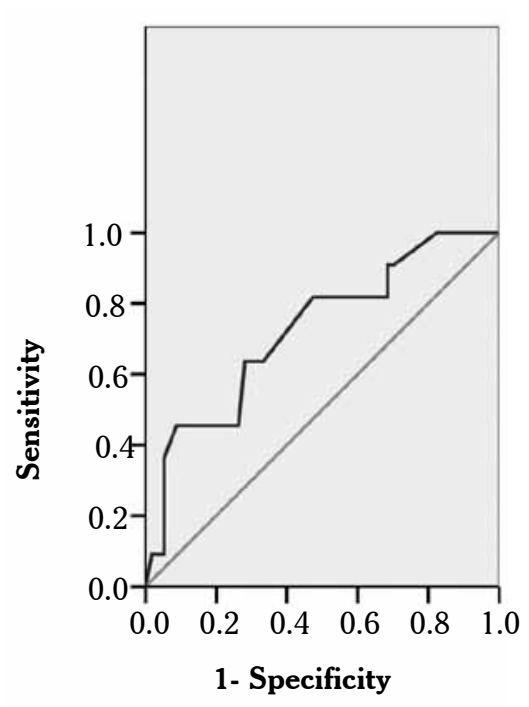

Figure 1. Receiver operator curve of endometrial thickness to predict persistent hyperplasia

Table 2. Number of persistent hyperplasia cases between women with higher and lower than $16.5 \mathrm{~mm}$ endometrial thickness

\begin{tabular}{|l|c|c|c|c|}
\hline $\begin{array}{l}\text { Endometrial } \\
\text { Thickness }\end{array}$ & $\begin{array}{c}<\mathbf{1 6 . 5} \\
\mathbf{m m}\end{array}$ & $\begin{array}{c}>\mathbf{1 6 . 5} \\
\mathbf{m m}\end{array}$ & Total & $\mathbf{p}$ Value \\
\hline Non persistent & 41 & 16 & 57 & \\
\hline Persistent & 4 & 7 & 11 & 0.029 \\
\hline Total & 45 & 23 & 68 & \\
\hline
\end{tabular}


In another study on endometrial hyperplasia, it was concluded that endometrial hyperplasia can be effectively excluded when the endometrial thickness is less than $7 \mathrm{~mm}$ (12). This data also confirms our hypothesis that endometrial thickness measurement directly gives information about the possibility of endometrial pathology.

There are still concerns about the treatment of endometrial hyperplasia without atypia, previous study concluded that the majority of women with atypical endometrial hyperplasia were managed by hysterectomy and the substantial risk of diagnostic under-call supports this approach to treatment. However, there is no consensus regarding the initial management of women with endometrial hyperplasia without cytological atypia (13). In another study with an aimsimilar to ours, it was found that among 13 clinical non-responders, 84.6\% might have associated pelvic pathology. Significant factors predicting clinical nonresponders included a history of prior bleeding, the presence of associated pelvic pathology and treatment using progestins other than MPA. The study concluded that the current regimens of progestin therapy for non-atypical endometrial hyperplasia have high response rates. Patients who fail to have a clinical response should be evaluated for associated pelvic pathology. Follow-up endometrial biopsy should be offered to the patients, because $7.5 \%$ have persistent or progressive lesions, necessitating aggressive treatment (14). In our study, the most commonly seen pelvic pathologies were not found to be associated with disease persistence.

A study estimated the clinical value of CA-125 in the diagnosis of endometrial carcinoma. It was found that there is an important correlation between serum levels of CA-125 and endometrial cancer (15). Based on this data, we assessed CA125 levels but did not find any significance.

Body mass index was found to be predictive of sonographic endometrial stripe thickness, which in turn is predictive of endometrial hyperplasia in patients with polycystic ovary syndrome. For every $1 \mathrm{~mm}$ increase in endometrial stripe, the odds ratio of hyperplasia increased by 1.48 (95\% confidence interval, 1.04-2.10) (5). This data shows the value of endometrial thickness measurement in hyperplasia.

Of the known risk factors for endometrial hyperplasia, obesity is the most preventable. Data suggest that higher BMI is associated with endometrial hyperplasia as compared to women with lower BMIs and abnormal bleeding (16). Contrary to this conclusion, our study did not reveal an association between BMI and disease persistence.

Although endometrial thickness measurement is a widely used simple and cheap method, in our literature search we have not encountered a study assessing its predictive value for treatment response in women with endometrial pathologies. This is the first study which shows a significant value of endometrial thickness in predicting treatment response in endometrial hyperplasia cases.

In conclusion, there are concerns about the optimal treatment for simple endometrial hyperplasia without atypia, and this study suggests that endometrial thickness measurement alone may predict response to therapy and this can be used to modify treatment.

\section{Conflict of interest}

No conflict of interest was declared by the authors.

\section{References}

1. Scully RE, Bonfiglio TA, Kurman, et al. Uterine corpus. In: Histological Typing of Female Genital Tract Tumours, 2nd ed., Springer-Verlag, New York 1994. p.13. [CrossRef]

2. Gambrell RD Jr. Progestogens in estrogen-replacement therapy. Clin Obstet Gynecol 1995; 38: 890. [CrossRef]

3. Ferenczy A, Gelfand M. The biologic significance of cytologic atypia in progestogen-treated endometrial hyperplasia. Am J Obstet Gynecol 1989; 160: 126-31.

4. Bódis J, Hanf V, Török A, Tinneberg HR, Borsay P, Szabó I. Influence of nicotine on progesterone and estradiol production of cultured human granulosa cells. Early Pregnancy 1997; 3: 34-7.

5. McCormick BA, Wilburn RD, Thomas MA, Williams DB, Maxwell R, Aubuchon M. Endometrial thickness predicts endometrial hyperplasia in patients with polycystic ovary syndrome. Fertil Steril 2011; 95: 2625-7. [CrossRef]

6. Dubinsky TJ, Stroehlein K, Abu-Ghazzeh Y, Parvey HR, Maklad N. Prediction of benign and malignant endometrial disease: hysterosonographic-pathologic correlation. Radiology 1999; 210: 393-7.

7. Kurman RJ, Kaminski PF, Norris HJ. The behavior of endometrial hyperplasia. A longtermstudy of „untreated“ hyperplasia in 170 patients. Cancer 1985; 56: 403-12. [CrossRef]

8. Lu FH, Tang SJ, Wu JS, Yang YC, Chang CJ. Hypertension in elderly persons: its prevalence and associated cardiovascular risk factors in Tainan City, southern Taiwan. J Gerontol A Biol Sci Med Sci 2000; 55: 463-8. [CrossRef]

9. Gunderson CC, Fader AN, Carson KA, Bristow RE. Oncologic and reproductive outcomes with progestin therapy in women with endometrial hyperplasia and grade 1 adenocarcinoma: a systematic review. Gynecol Oncol 2012; 125: 477-82. [CrossRef]

10. Kalampokas T, Gregoriou O, Grigoriadis C, Iavazzo C, Zervakis A, Sofoudis $\mathrm{C}$, et al. Comparing transvaginally defined endometrial thickness with hysteroscopic and histopathologic findings in asyptomatic postmenopausal women. Eur J Gynaecol Oncol 2012; 33: 508-11.

11. Bezircioglu I, Baloglu A, Tarhan MO, Oziz E, Yigit S. Evaluation of endometrium by transvaginal ultrasonography and Doppler in tamoxifen-treated women with breast cancer. Eur J Gynaecol Oncol 2012; 33: 295-9.

12. Cheung AP. Ultrasound and menstrual history in predicting endometrial hyperplasia in polycystic ovary syndrome. Obstet Gynecol 2001; 98: 325-31. [CrossRef]

13. Clark TJ, Neelakantan D, Gupta JK. The management of endometrial hyperplasia: an evaluation of current practice. Eur J Obstet Gynecol Reprod Biol 2006; 125: 259-64. [CrossRef]

14. Rattanachaiyanont $M$, Angsuwathana S, Techatrisak K, Tanmahasamut P, Indhavivadhana S, Leerasiri P. Clinical and pathological responses of progestin therapy for non-atypical endometrial hyperplasia: a prospective study. J Obstet Gynaecol Res 2005; 31: 98-106. [CrossRef]

15. Yu B, Xu PZ, Wang QW, Zhou H, Zhou HX. Clinical value of tumour specific growth factor (TSGF) and carbohydrate antigen-125 (CA-125) in carcinoma of the endometrium. J Int Med Res 2009; 37: 878-83. [CrossRef]

16. Heller DS, Mosquera C, Goldsmith LT, Cracchiolo B. Body mass index of patients with endometrial hyperplasia: comparison to patients with proliferative endometrium and abnormal bleeding. $\mathrm{J}$ Reprod Med 2011; 56: 110-2. 